\title{
CS-05 - Importancia de la multidisciplinariedad en el análisis de grupos conflictivos
}

\author{
Importance of multidisciplinarity in the analysis of conflicting groups \\ Antonio Minera \\ Dirección General de Investigación, Universidad San Carlos de Guatemala
}

Autor al que se dirige correspondencia: minera.antonio@gmail.com

\section{Resumen}

$\mathrm{E}$ 1 análisis de colectivos o grupos de personas que desarrollan actividades fuera de los parámetros permisibles de comportamiento social debe hacerse desde una perspectiva multidisciplinaria. Estos grupos pueden alcanzar extremos de violencia que, consecuentemente, ocasionan conflictos contra la naturaleza, la sociedad,el ambiente, y específicamente, contra los demás individuos. Las autoridades y la legislación aplicable, permiten adentrarse en dinámicas de acción, cada vez más comunes, existentes en diversos escenarios urbanos y susceptibles al análisis desde diferentes perspectivas, ámbitos y corrientes de pensamiento, capaces de profundizar en la multiplicidad de aspectos relacionados con el fenómeno. La participación multidiscipinaria en el abordaje es fundamental porque permite comprender fenomenologías inherentes desde diferentes planos de opinión, comprensión y tratamiento, en función de la postura proveniente de su interpretación particular desde su propio campo de aplicación de la ciencia social, complementándose entre sí en la objetividad de sus planteamientos individuales. Lo que ha permitido obtener, en sus distintas aplicaciones, productos sustantivos, avances del conocimiento y aportes fundamentales en materia de grupos conflictivos.Asimismo, adentrarse en elementos característicos de la dinámica social que desarrollan y de los personajes que los constituyen, esto brinda información trascendental y propuestas de solución a los gobiernos locales, municipales o estatales, tanto a la problemática que plantea la existencia de este tipo de conglomerados (hordas, tribus o subculturas urbanas), como en materia de prevención de violencia y delito.

Palabras clave: Colectivos antisociales, pandillas, sociología urbana, manuales administrativo, organizaciones conflictivas.

\section{Abstract}

$\mathrm{T}$ he analysis of groups or groups of people who develop activities outside the permissible parameters of social behavior must be done from a multidisciplinary perspective. These groups can reach extremes of violence that, consequently, cause conflicts against nature, society, the environment, and specifically, against other individuals. The authorities and the applicable legislation allow us to delve into action dynamics, increasingly common, existing in various urban scenarios and susceptible to analysis from different perspectives, scopes and currents of thought, capable of deepening in the multiplicity of aspects related to the phenomenon. The multidisciplinary participation in the approach is fundamental because it allows understanding inherent phenomenologist from different levels of opinion, understanding and treatment, based on the position coming from its particular interpretation from its own field of application of social science, complementing each other in objectivity of their individual approaches. What has allowed obtaining, in its different applications, substantive products, advances in knowledge and fundamental contributions in the area of conflictive groups. Also, to delve into characteristic elements of the social dynamics that they develop and the characters that constitute them, this provides transcendental information and proposals for solutions to local, municipal or state governments, both to the problems posed by the existence of this type of conglomerates (hordes, tribes or urban subcultures), and in terms of the prevention of violence and crime.

Keywords: Antisocial groups, gangs, urban sociology, administrative manuals, conflicting organizations. 